\title{
Elizabeth Bowes and John Knox: A Woman and Reformation Theology
}

\section{A. Daniel Frankforter}

Medieval civilization was centered on theology. Theology inspired its arts, and theology shaped its research in science, law, medicine, and philosophy. The dancers at the court of the queen of sciences were mostly male, and one wonders what their female contemporaries thought or knew of the theological issues that were fundamental to the culture of the period. ${ }^{1}$ By the end of the Middle Ages it is probable that there was a high literacy rate among women of the middle and upper classes. ${ }^{2}$ Although it is unlikely that these women remained ignorant of the major debates that enlivened the conversations of educated men, evidence of their participation in theological endeavors is scant. Since women were excluded from the universities and formal training in the techniques of scholastic argument, it was virtually impossible for them to develop careers as professional thinkers.

Some women did stray onto the turf of male intellectual preserves. Inquisitors confronted female heretics who were eager to argue theology. ${ }^{3} \mathrm{~A}$ few women, like Abelard's Heloise, had opportunities for contacts with university communities and knew something about the conversations of the academy. The unique Christine de Pizan acquired enough education through a program of independent readings to write popular textbooks on moral philosophy. No woman, however, was recognized as a theologian. ${ }^{4}$ The women who contributed most to theology were mystics whose visions derived from inspiration. As passive instruments of God, they produced spiritual raw material for the expository mills of male scholars. ${ }^{5}$

1. Mary R. Lefkowitz, "Women in Greek Myth," American Scholar 54 (1985): 209, poses the same question about ancient Greek women and the mythology that structured their culture.

2. Lowell Green, "Education of Women in the Reformation," History of Education Quarterly 19 (1979): 93-116. A more conservative position is taken by Retha M. Warnicke, Women of the English Renaissance and Reformation (Westport, Conn., 1983), p. 3. Jo Ann Hoeppner, The Growth of English Schooling, 1340-1548: Learning, Literacy, and Laicization in Pre-Reformation York Diocese (Princeton, 1985), presents evidence for schools in the area where Knox worked.

3. Shulamith Shahar, The Fourth Estate: A History of Women in the Middle Ages (London, 1983), p. 259.

4. Ibid., p. 52. Dean G. Peerman and Marty E. Marty, eds., A Handbook of Christian Theologians (Nashville, 1984), list the members of what is still a male club.

5. Keith Thomas, Religion and the Decline of Magic: Studies in Popular Beliefs in Sixteenth and Seventeenth Century England (New York, 1971), p. 137; Katharina M. Wilson, Medieval Woman Writers (Athens, Ga., 1984).

Mr. Frankforter is associate professor of history in Behrend College, Pennsylvania State University, Erie, Pennsylvania. 
Despite the fact that medieval women were not formally schooled in systems of abstract thought, their behavior indicates that they could not have been ignorant of theology or indifferent to it. When the Reformation erupted many women immediately comprehended what it was about, embraced its faith, preached its message, and encouraged its leaders. Women hovered about the first generation of Protestant churches just as the Priscillas and Phoebes flocked to the congregations of the apostle Paul. Historians have been slow to acknowledge their contribution to the Reformation, for most of the reformers recognized and rewarded the services of women with expressions of gratitude that were as lukewarm as those of Paul. The church rarely has honored women as enthusiastically as women have served it. ${ }^{6}$

Female theologians were as uncommon in the sixteenth century as they had been in earlier eras, but women did write to Protestant leaders about theological issues. Some Protestant theologians used their correspondence as a substitute for the Catholic confessional. ${ }^{7}$ But it would be a mistake to dismiss all their letter writing as a one-sided pastoral service. In some cases women guided, or at least stimulated, the thoughts of the famous men who befriended them.

One of the women of the sixteenth century who has not always been given her due in this regard is Elizabeth Aske Bowes, close friend, long-term correspondent, and mother-in-law of John Knox. The course of Mrs. Bowes's thought is difficult to reconstruct, for all her letters have disappeared. Their contents are reflected in the thirty letters that Knox wrote to her, but interpretation of Knox's letters is complicated by uncertainty about their chronological order. Most of them (29) survive only in a transcription of their texts that was made in $1603 .^{8}$ These letters exist because Mrs. Bowes saved many, but not all, of Knox's letters and returned them to him after her daughter married Knox. ${ }^{9}$ Near the end of his life Knox mentioned having the letters among his papers. ${ }^{10}$ They probably were copied in the form in which we now have them by an associate of his second wife and guardian of his estate, Margaret Stewart. Since Knox had neglected to date many of his letters, the copyist was forced to guess at their order. ${ }^{11}$ Years were suggested

6. Jane Dempsey Douglass, "Christian Freedom: What Calvin Learned at the School of Women," Church History 53 (1984): 155-173; Richard Greaves, ed., Triumph Over Silence: Women in Protestant History (London, 1985).

7. Natile Davis, "City Women and Religious Change," in Society and Culture in Early Modern France (Stanford, 1975), pp. 65-95.

8. The manuscript is housed in the library of the University of Edinburgh. The dedication of Knox's Commentary on the Sixth Psalm is also a letter to Bowes.

9. There is no letter that clearly marks the beginning of their correspondence.

10. John Knox, "An Answer to a letter of a Jesuit Named Tyrie," in: John Knox, The Works of John Knox, ed. David Laing, 6 vols. (Edinburgh, 1846-1864), 6:514. (This collection hereafter will be cited as Works.)

11. Seven letters were transcribed without any dates; thirteen were entered with only an indication of the year when they were written. Since the year is usually obvious to a letter's 
for all but seven of the letters, but some of the dates supplied in the manuscript are demonstrably wrong, and most are suspect. Apart from a very few letters that can be dated securely, the vast majority can be given a context only by relying on evidence that is highly circumstantial or conjectural. The subjects discussed in some of the letters do indicate at least a probable sequence for their composition. ${ }^{12}$

Confusion concerning the chronology of Knox's letters has encouraged readers to deal with his correspondence with $\mathrm{Mrs}$. Bowes as if it were a homogenous lump. When treated this way, the Bowes-Knox conversations give the impression of having had no development and having made no progress. The same questions come up over and over again, and Mrs. Bowes seems not to understand what she is told. Scholars frequently have dismissed her, therefore, as a pitiful neurotic - an "unstable ... spiritually disturbed" woman whose "morbid scrupulosity" proves her to have been a "spiritual hypochondriac." ${ }^{\text {"13 }}$ All such assessments of Mrs. Bowes should be entertained with caution, for they run counter to the opinion of the man who knew her best, John Knox.

Knox's relationship with Mrs. Bowes was a puzzle to his contemporaries and an opportunity for his enemies to encourage suspicion of misconduct. Knox's Catholic opponents accused Mrs. Bowes of being her son-in-law's mistress, and even a modern scholar as reputable as Hugh Trevor-Roper has enjoyed hyperventilating by sniffing for smoke in a place where there is likely to be no fire. ${ }^{14} \mathrm{Mrs}$. Bowes was nine years older than Knox, and, when they met, she had been married for thirty years and had borne fifteen children. During the period of her most frequent correspondence with Knox she fought successfully to overcome her family's resistance to Knox as a suitor for her daughter Marjorie. Knox's inferior social origins, Scottish background, and priestly status made him a less-than-ideal connection in the opinion of Marjorie's male relatives. Given all these factors it is unlikely that an illicit carnal relationship would have flourished, particularly between people

recipient, an author is not likely to take the trouble to record it and then omit mention of the month or day. Indications of year alone are, therefore, probably the work of an editor.

12. For a reconstruction of this sequence, see $A$. Daniel Frankforter, "The Chronology of the Knox-Bowes Correspondence," Manuscripta (forthcoming).

13. Richard Kyle, "The Concept of Predestination in the Thought of John Knox," Westminster Theological Journal 46 (1984): 59, 55; Patrick Collinson, "The Role of Women in the English Reformation Illustrated by the Life and Friendships of Anne Locke," Studies in Church History, ed. G.J. Cuming (London, 1965), p. 264; Richard Greaves, "The Nature of Authority in the Writings of John Knox," Fides et Historia 10 (1978): 47. Jasper Ridley, John Knox (Oxford, 1968), p. 131, notes that "it is fashionable today to laugh at Mrs. Bowes." If Mrs. Bowes's spiritual sensitivity seems excessive to us, it was not unique to her or to her sex. See Knox's correspondence with Thomas Upcher (Works, 4:241-243), discussed by W. Stanford Reid, "John Knox, Pastor of Souls," Westminster Theological Journal 40 (1978): 7.

14. Hugh Trevor-Roper, "John Knox," in The Listener 80 (1968): 747. 
burdened with consciences as scrupulous as those possessed by Knox and Elizabeth Bowes. Nothing in their letters points to anything but friendship between them. ${ }^{15}$

Mrs. Bowes was, however, a strong woman who was quite prepared, when she deemed it necessary, to ignore social conventions. When the death of Edward VI dashed Knox's hopes for a career in England, he was forced penniless into exile. Under these circumstances Marjorie's father and uncle had no intention of honoring her engagement to Knox. They dismissed him with brutal words and hastened to make their peace with the new Catholic order. Mrs. Bowes refused to fall in line with their plans. She and Marjorie crossed the border into Scotland, and there, against the wishes of her father, Marjorie married Knox. ${ }^{16}$ Knox, his wife, and Mrs. Bowes subsequently found asylum in Geneva. Marjorie bore two sons, and after her death in 1560 her mother stayed on in Knox's house to care for the children until Knox remarried in 1564. Mrs. Bowes eventually returned to England and died there not long before Knox's final illness.

After Elizabeth Bowes's death Knox felt that it was his duty to publish a defense of their friendship. ${ }^{17} \mathrm{He}$ denied that his affection for her had contained any element of fleshly desire, and he claimed that it derived entirely from his respect for her spiritual qualities. Knox's praise of Mrs. Bowes was extremely generous. He declared her struggle with faith to have been the finest example of Christian heroics that he had ever witnessed. He wrote: "in Scotland, Ingland, France, and Germanie, I have heard the complaintes of divers that feared God, but of the lyke conflict as she susteyned, fra the tyme of her first acquentance, and long before . . . till this hour, I have not knowen." ${ }^{18}$ Even this encomium, however, was not as complete or objective a public disclosure of Knox's relationship with Mrs. Bowes as it might have been. Although he admitted in passing that he had taken some comfort from her company, he complained that her troubles were often a cross laid on him and implied that he gave far more than he got in their association. Ignoring what he had written privately to her, he stressed his pastoral services to her and chose to say little about her influences on him.

Knox's sexism made it difficult for him to acknowledge the full significance of the example that Mrs. Bowes's spiritual struggle set for him. Knox was

15. Letter 3 (in the numbering of the 1603 transcription), the "Alnwick cupboard" letter, is the only one ever cited as containing a possible, veiled reference to a moment of carnal temptation. Such a meaning can be given to the letter only by ignoring its context. See discussion below.

16. Ridley notes that Richard Bowes omitted his wife and daughter from his will and explicitly stated that his unmarried daughters should lose their portions if they married against the wishes of their uncles; Ridley, John Knox, p. 143.

17. Knox, "An Answer to a Letter of a Jesuit Named Tyrie," Works, 6:513-520.

18. Ibid., 6:513. 
absolutely convinced that all women were destined by God and nature to defer to all men. Female inferiority was, he believed, an indisputable fact demonstrated by the rational arguments of pagan philosophers, consistently described by the historians of all nations since the beginning of time, and blessed by the mandates of scripture. ${ }^{19}$ It amazed him, therefore, when he, "one of Godis cheif ministers," was equaled in spiritual sensitivity by a woman. ${ }^{20} \mathrm{He}$ remarked several times, with condescending wonder, that Mrs. Bowes was his match as a spiritual athlete, and he assured her (because he assumed that she must think otherwise) that his comparison of her humble situation with his own exalted calling was not mere flattery. ${ }^{21}$ Amazed as Knox was at Mrs. Bowes's spiritual depths, he was not prompted to reconsider his prejudices against women. At the end of his life, when he came to look back over their relationship and compose his public defense of it, he preferred to remember himself as Mrs. Bowes's pastor, teacher, and guide. ${ }^{22}$ But his letters to her witness to the fact that she was not a passive disciple in a one-sided relationship. In the private letters he told her that he held her up as a model to others. He admitted that her questions caused him to prove the meaning of scripture more deeply than ever he would have on his own. He confessed that she was a mirror to him of his own soul and the reflected image of his personal struggle with faith. And he lamented, when they were parted, that he was deprived of the spiritual solace of her company. ${ }^{23}$ Since Knox is not known for his gallantry toward women, his declaration of respect for her religious concerns should be taken seriously and his correspondence with her should be examined for signs of influences she may have had on his development. ${ }^{24}$

W. Stanford Reid has argued that Knox offered Mrs. Bowes "the Protestant doctrine of justification of faith alone" as the solution to her anxiety about her salvation, but Knox's letters suggest that Reid may have reversed the order of things. ${ }^{25}$ The Protestant concept of grace was more the source of Mrs. Bowes's concerns than the solution to her problems. John Knox did not convert Elizabeth Bowes to Protestantism. He reports that her

19. This argument was advanced in Knox's tract, "The First Blast of the Trumpet Against the Monstrous Regiment of Wemen," Works, 4:365-420.

20. Works, 3:340 (Letter 1).

21. Ibid., 3:348-350 (Letter 3), and 3:379-380 (Letter 18.2).

22. Ibid., 6:514. Knox did admit to insufficiency in these roles.

23. Ibid., 3:379-380 (Letter 18.2); 3:379, 338 (Letters 18.2 and 1); 3:338, 350 (Letters 1 and 3); 3:337-338 (Letter 1).

24. The First Blast is the most famous example of Knox's misogynistic rhetoric, but it is not unique. Ridley claims that during the course of his life Knox grew progressively less "balanced" on the subject of women, John Knox, p. 475. Richard Greaves, "John Knox and the Ladies, or the Controversy Over Gynecocracy," Red River Valley Historical Journal 2 (1977): 6-16, disagrees.

25. Reid, "John Knox," p. 4. 
spiritual struggle began "long before" he first made her acquaintance, and Knox was not her only source of information about Protestant doctrine. ${ }^{26}$ Mrs. Bowes was an avid reader of the Bible who did not accept what Knox told her without question. She was persistent in thinking through the implications of his pronouncements and bold in pointing out apparent inconsistencies between his words and the scriptures.

Mrs. Bowes pressed Knox to think about the implications of salvation by faith. She brought up scriptural passages that seemed to contradict his explanation of it, and she forced him to confront the psychological dimension of the believer's struggle to come to terms with the idea of divine election. He admitted to her that her struggle was the image of his own, and her courage in confronting her doubts helped him to face up to his own. ${ }^{27}$ The earliest dateable letter from Knox to Mrs. Bowes was written on Tuesday, 22 December 1551, two and a half years after Knox took up his post as pastor of Mrs. Bowes's parish in Berwick. The letter speaks to Mrs. Bowes's inability to feel God's presence and an assurance of her salvation at all times. Mrs. Bowes knew that true Christians were saved by God's gift of grace, but she was concerned that she could find little evidence of that miracle within herself. Knox insisted that her experience was one of the normal trials of faith. The saved, Knox confessed, "heir not alwayis Godis Word vocallie crying unto us." Even Christ on the cross had the feeling of being abandoned by God while in the very act of making "satisfactioun to the justice of God." A feeling of alienation from God was useful for the development of Christian life, for it forced the Christian to confront her worthlessness and to realize that the only hope of salvation lay with God. The experience of one's inadequacy revealed the true vanity of the things of this world and kept the Christian from sinking to the level of the "brute beastis" that seek nothing but the pleasures of the flesh. It created the state of mind that was necessary for salvation - a desire to receive salvation as a gift made possible by the blood of Christ. Anxiety about damnation was a sign of salvation, for it indicated that grace had awakened the conscience to confront the fact that salvation could come only through Christ. ${ }^{28}$

Mrs. Bowes was not easily convinced that her doubt was a sign of grace. In his next letter Knox cited Chrysostom's commentary on the parable of the wheat and the tares to strengthen his case. Chrysostom warned that those whom God loves are the targets of special attacks from the devil. Their trials,

26. Works, 6:513-520. Bowes's letters often addressed questions to him that were inspired by her own research; see, for example, ibid., 3:365-368 (Letter 13).

27. Ibid., 3:338, 348-350 (Letters 1 and 3).

28. Ibid., 3:353-355 (Letter 6). This was not the first letter they exchanged, for it refers to earlier questions she addressed to him which he had not had time to answer. There is no compelling reason, however, to date any of the other extant letters earlier than this one. The manuscript ascribes the letter to 22 December 1553, but two references to days of the week within the text prove that it was written in 1551 . 
therefore, should be a joy to them, for their sufferings are evidence of their salvation. Mrs. Bowes was concerned, however, that there were scriptural passages that warned the sinner to take her doubts more seriously. She called Knox's attention to Jesus's warnings in Luke 13:24 that "many will seek to enter and will not be able" and in Matthew 22:14 that "many are called, but few are chosen." Knox insisted that the first of these passages was directed only against people who sought the kingdom of God by means other than grace. The second, he explained, should comfort her, for she knew how many in England were invited to faith and how few responded to the call. The fact that she was out of step with most people was another of the signs of her salvation. ${ }^{29}$

Sometime after the receipt of this letter (early in 1552), Mrs. Bowes had a meeting with Knox that may have been a turning point in their relationship. To discharge his duties as a preacher Knox travelled between Newcastle and Berwick, a distance of about sixty miles. His early letters all note that he suffered from a kidney or stomach ailment of some kind. If he was feeling unwell, the village of Alnwick would have been a convenient place to break the trip between his two bases, and it would have been easy for Mrs. Bowes, particularly if she was concerned for his health, to go out from her home to meet him there. In February of 1552 they had a serious conversation while "standing at the copburd in Anwik [sic]." Mrs. Bowes poured out her heart to Knox more plainly than before, and he handled her self-disclosure badly. $\mathrm{He}$ "did start bak" from her confession, and she took his action as a rebuke. She reported her disappointment to another member of Knox's congregation, Harie Wickleif, and he relayed it to Knox. Knox hastened to explain himself. Like many males he was not adept at showing his feelings, and he admitted that it was "my commoun consuetude, when any thing perceth or tuicheth my hart," to shy away from it. Mrs. Bowes had broken through his defenses at Alnwick and forced him to see what was in his heart. He was jolted to realize that others were "tempted" as he was, and he was shaken by Mrs. Bowes's ability to articulate dark thoughts that he had kept to himself. He wrote: "when that I heard proceid fra your mouth the verie same wordis that he [Satan] trubillis me with, I did wonder, and fra my hart lament your sair trubill, knawing in my selfe the dolour thairof." Knox tried to comfort Mrs. Bowes by reminding her that a Christian's peace of mind derived solely from the knowledge that Christ alone had the power to triumph over sin. Christ did for sinners what they could never hope to do for themselves. Knox admitted that in her present mood-a sickness of the soul-she could not stomach the "hailsum fude" of the scriptural promises. But her transient

29. Ibid., 3:350-352 (Letter 4). This letter cannot be securely dated, but circumstantial evidence places it between letters 6 and 3. In it Knox continues to complain of his illness. The texts he explains deal with the theme of letter 6 , and the return to Berwick which he announced could have led to the meeting with Mrs. Bowes at Alnwick which he discusses in letter 3. 
brush with despair was not indicative of the real state of her soul, for, although tormented by doubts, she sought help from authentic Christian advisors. The truly reprobate persecute the faithful; they do not look to them for comfort. Knox also reminded Mrs. Bowes that she had previously (at least on the occasion of her conversion) experienced the taste of the "sueitnes of Godis promissis." That was something that the damned never know, for God "can not repent him of his giftis." Those who have once embraced Christ, turned their backs on idolatry (that is, Catholicism), confessed their faith, and loved other members of Christ's body cannot be deceived. If God granted them misleading experiences of his grace, then he would be either inconsistent or a liar. Since neither of these demeaned states is compatible with his majesty, God cannot withdraw the grace he has once given. ${ }^{30}$

Mrs. Bowes's spiritual state was dramatic, but Knox did not find it ridiculous or pathological. He identified with it, and after their conversation in Alnwick he did not hesitate to let her know that. He warned Mrs. Bowes that in this life the faithful must undergo the experience of knowing "thame selves almaist brunt in hell." He admitted that he felt himself to be weighed down with the sufferings of Job, and, although he knew that God could come to his aid, his pain made it difficult to believe that he would be delivered. This was not an easy confession for him to make, and he pointed out to Mrs. Bowes that his words were "mair plane than ever I spak" and were offered to let her know that she had "ane fellow and companyoun in trubill." His respect and concern for her was such that he went beyond self-disclosure. To comfort her he was willing boldly to proclaim that in her case he was certain of the mind of God: "In my conscience I judge and be the Halie Spreit of my God, am fullie certifeith that ye are a member of Chrystis bodie." 31

Mrs. Bowes may have appreciated Knox's oaths and assurances, but she hoped for more. She sought understanding of scriptural passages that seemed at odds with the doctrines Knox taught. She wrote to ask about texts that bore on the arguments he had made following their conversation in Alnwick. The story of the angel of God wrestling with Jacob bothered her, for it seemed to be a tale about a man who won salvation by his own works. Knox insisted that it was an elaborate metaphor for grace. Jacob feared that Esau would destroy him despite God's promises, so God demonstrated the invincibility of divine grace by giving Jacob a victory over a creature far greater than Esau. Jacob's determination to cling to the angel despite the crippling injury to his thigh was a reminder that Christians should hang on to the promises of God even when there is no hope of a triumph through the flesh. Jacob's belief that he

30. Ibid., 3:349-350 (Letter 3). The letter is dated 26 February 1553, but since Knox was in London on that date, not in Newcastle as the letter states, the letter was probably written on 26 February 1552.

31. Ibid., 3:352-353 (Letter 5). The letter is assigned a context by the fact that it comes from the period of Knox's illness and celebrates a new degree of openness between the two friends following on the Alnwick cupboard conversation. 
had seen God face-to-face was not to be taken literally. Moses affirmed that no human being could bear the sight of God's majesty. Therefore God had appeared to Jacob in the angel as he appears to the faithful in Christ. He was perceived, not by bodily sight, but by the spirit. ${ }^{32}$

Knox issued another warning about the dangers of reading scripture literally when Mrs. Bowes asked about the assertion in 1 Samuel 15:35 that God repented making Saul a king. The passage troubled Mrs. Bowes, for in his letter written after their conversation in Alnwick Knox had assured her that God could not "repent" the giving of his gifts of grace. ${ }^{33} \mathrm{Mrs}$. Bowes had good reason to wonder why God could not abandon her if he had changed his mind about Saul. Knox defended his position by insisting that all these stories used metaphorical language. He noted that scripture speaks of God as if he had the "memberis" and "mutabill passionis" of a man, but no such things can really exist in the Godhead. Knox insisted that from the beginning God knew what Saul would do and that Saul "always was reprobat, and never did imbrace the promeis of remissioun and reconciliatioun." Saul's promotion to a position of worldly dignity was no sign of God's favor, for many who enjoy exalted positions on earth have no claim to preference in heaven. Knox insisted that a Christian's security stemmed solely from confidence in God's word. And God had assured the faithful that people who know their own worthlessness and place all their hope for redemption in Christ cannot be separated from God. ${ }^{34}$

Mrs. Bowes, however, could not be sure she felt the requisite degree of trust in God's word. On 26 July 1552 Knox sent her a letter that addressed her fears about the culpability of her lack of trust in God. He admitted that the inability of Christians to be as perfect in faith as they knew they should be was painful to them, but it was not a reason for despair. The shortcomings of the saved were not held against them, for salvation came through a faith "whilk is the frie gift of our God, and not proceiding of our workis." 35

32. Ibid., 3:397-402 (Letter 26). The transcriber of the manuscript of 1603 gave this letter no date at all, and it contains no personal or historical references. The scriptural passages discussed in it do correspond, however, to questions that letter 3 might have raised in any reader's mind.

33. Ibid., 3:362-364 (Letter 11). Letter 26 (above) closes with a note in which Knox acknowledges receipt of another letter asking about another passage. He says he will answer it when he can. Letter 11 may be the promised response, for its theme is consistent with questions raised by letter 3 .

34. Knox did not offer or follow consistently the exegetical advice he gave Mrs. Bowes. When Mary Stewart suggested that his interpretations of scripture were only his opinions, he objected that there would be no confusion about the meaning of texts were it not for sinners who "obstinately remain ignorant"; The History of the Reformation in Scotland, in Works, 2:331-335. Knox himself inclined toward literalism. See Richard L. Greaves, "Nature of Authority"; Richard Kyle, "John Knox and Apocalyptic Thought," Sixteenth Century Journal 15 (1984): 457-458.

35. Works, 3:358-360 (Letter 9). The letter is ascribed erroneously by its 1603 editor to 1553 . It was written from Carlisle, and Knox was in Carlisle in July of 1552 on his way to court in the train of the Duke of Northumberland. Ian Torrence, "Patrick Hamilton and John 
Knox's simple assertion of the doctrine of salvation by grace inspired Mrs. Bowes to write back and ask for an answer to an obvious question-one that Paul had anticipated in Romans 6. If we are securely saved by Christ and designated among the elect by a God who cannot change his mind, are our thoughts and deeds deprived of all significance? If the works of Christian people do not matter, then does Christian faith matter ? ${ }^{36}$

The question Mrs. Bowes posed was doubtless one that had plagued Knox, and he was not prepared to deal with it. In raising it she inadvertently struck a nerve, and Knox spoke more sternly to her than in any of his other letters. Instead of venturing an explanation of the paradox of faith and works, he chose to attack her motives in raising the issue with him. He insisted, with Paul, that although her deeds would not be imputed to her, she should not indulge thoughts and acts that transgressed God's commandments. The fact that ideas like this one could occur to her was a sign of how viciously Satan fought against her faith. He ordered her to "lament and murne that any sic motioun suld remane in you" and to desire "to be maid frie fra that corruptioun by your campioun, Chryst. ${ }^{37}$ Knox must have been thrown off balance by Mrs. Bowes's question, for it was not an act of pastoral wisdom to urge a woman as sensitive as Mrs. Bowes to additional self-incrimination.

Mrs. Bowes sank deeper into depression. She feared that she had committed the "sin unto death" for which there was no forgiveness and that Knox had given up hope for her. Despair made her nostalgic for the Catholic mass. ${ }^{38}$ The logic of the Catholic sacramental system's solution to the problem of sin appealed to a mind exhausted by Protestant puzzles.

Knox sent Mrs. Bowes a hasty note in which he insisted that he had never meant to imply doubt about her salvation, and he offered her another oath to that effect: "I am evin equallie certified of your electioun in Chryst, as that I am that I myself preacheth Chryst to be the onlie Saviour." Further, he advised her that the "sin unto death" was a desire to return to Catholicism out of contempt for God's word, not mere human weakness. He believed that there was no such impulse in her heart, and he urged her to fight Satan's snares. $^{39}$

December and January 1552-1553 were a bad season for Mrs. Bowes. She and Knox corresponded frequently. In addition to her longstanding spiritual troubles, her family life may have been tense. Negotiations for Knox's engagement to Marjorie finally came to a head. An agreement between

Knox: A Study in the Doctrine of Justification by Faith," Archiv für Reformationsgeschichte 65 (1974): 171-184, demonstrates Knox's belief that redeemed sinners are still sinners.

36. Ibid., 3:364-365 (Letter 12). Knox was still in Carlisle when he wrote.

37. Ibid.

38. Ibid., 3:369 (Letter 14).

39. Ibid. 
Marjorie and Knox was reached before Knox's departure from Newcastle for London in January of $1553 .^{40}$

The list of Mrs. Bowes's spiritual complaints grew alarmingly. She continued to write about the temptation she felt to return to the comforts of Catholic "idolatrie." ${ }^{\text {11 }}$ In her worst moments she questioned the existence of God, and she doubted the truth of the stories told about Jesus. ${ }^{42}$ She compared herself to an infamous lapsed Protestant, Francis Spira, who yielded to Catholic pressure and repudiated his reformed faith. ${ }^{43}$ And, in a letter that shocked Knox, she accused herself of the sins of Sodom and Gomorrah. ${ }^{44}$ (Knox hastened to assure her that she had no idea what she was talking about.)

Knox used several strategies in dealing with her confessions. He tried ridicule. He sneered at the mass as "prayer unto breid," implying that he could not believe that she was attracted to such an absurd thing. ${ }^{45}$ He tried logic. He asked her why, if she really doubted the existence of God in her heart, she was terrified by this thought. If she truly believed that there was no God, who would hold her accountable for her lack of faith $?^{46}$ He tried a psychological appeal, arguing that knowledge of one's insufficiency was a necessary precondition of grace and a sign of salvation. ${ }^{47}$

Mrs. Bowes's ability to pose questions easily matched Knox's resourcefulness in answering them. What Knox hoped to bring her to, as a solution to her problems, was not a rational acceptance of Protestant doctrine, but a leap of faith. He wrote: "Stik ye onlie to the treuth of Godis Word: Onlie, I say beleif and ye salbe saif. And albeit ye find not sic perfectioun as ye desyre, yit cry with the man that was sair trubillit, 'Lord, I beleif, help my unbeleif.'

It was easy to urge the leap of faith on a woman who felt as incapable of Christian heroics as did Mrs. Bowes. But Knox tried to convince her that she already was what she doubted her ability to become-an authentic heroine of faith. From London he wrote to say that he had read her most recent letter to "thrie honest pure wemen" who had come to him for counsel. They were profoundly moved by her words, and her superior experience in wrestling with the demons of doubt had inspired one of the women to exclaim: "O wald

40. Thereafter Knox addressed Mrs. Bowes as "mother" rather than "sister." Eight of his thirty letters to her may have been written in December-January, 1552-1553 (14, 10, 9.2, 13, 24, $7,8,20)$.

41. Works, 3:361-363 (Letter 10). For the equation of the mass and "idolatrie" in the correspondence, see Letter 15 (ibid., 3:371).

42. Ibid., 3:360-361 (Letter 9.2); ibid., 3:372-374 (Letter 16).

43. Ibid., 3:365-368 (Letter 13).

44. Ibid., 3:382-385 (Letter 20).

45. Ibid., 3:361 (Letter 10).

46. Ibid., 3:360 (Letter 9.2)

47. Ibid., 3:374 (Letter 16).

48. Ibid., 3:367 (Letter 13). 
to God I mycht speik with that persone, for I persave that thair be ma tempted than I."49

In his next letter Knox continued the same theme. He assured Mrs. Bowes that "God hath wrocht greit thingis be yow in the syght of uthir men." Mrs. Bowes had written to report that her storm of doubt had yielded to an equally troublesome state. She now felt lethargic and indifferent to her sins. Knox assured her that to a degree this reaction was normal. The spirit, like the body, needed periods of rest from its labors. He, too, had felt what she described. ${ }^{50}$

A few months later Knox sent Mrs. Bowes a long, complimentary letter that assured her that she stood with him in the ranks of the champions of the faith. He told her that although he had found her company delightful from the first day of their acquaintance, he had not always appreciated the full significance of their conversations. Now that he had been separated from her for some time he realized that God had used their talks to bring them both closer to faith and that her frank confessions of her own problems had clarified his spiritual condition to him: "The exposition of your trubillis, and acknawledging of your infirmitie, war first unto me a verie mirrour and glass whairin I beheled my self sa rychtlie payntit furth, that nathing culd be mair evident to my awn eis." Her ability to anticipate his thought amazed him. He reported that the letter he had just opened from her, as others before it, spoke directly to the very thing that he was pondering when he received it. Knox was not prepared to recognize Mrs. Bowes as an equal, but he urged her to take comfort from the fact that God deemed her worthy to endure the same trials imposed on his "cheif ministeris," the men "to whom God hes gevin greatter giftis." Despite her gender and her humble station in the church, God knew her to be capable of withstanding the full brunt of Satan's attack, and God dealt with her as with the mighty men who were the leaders of the faith. $^{51}$

Mrs. Bowes drew little assurance from Knox's recognition of the heroic proportions of her religious struggle. Her sense of sin and alienation was greater than her confidence in God's love and mercy. Knox chided her for seeming to believe that her iniquity could defeat the power of God's grace, and he encouraged her in a potentially confusing line of thought. Knox ignored some of Jesus's harder teachings (such as Matt. 5:28 and 15:19) and urged Mrs. Bowes to "mak divisioun betwene the suggestionis, assaltis, and

49. Ibid., 3:379-380 (Letter 18.2). The letter is dated reliably in the manuscript to 1 March 1553 when Knox was in London.

50. Ibid., 3:386-387 (Letter 21). The letter might be dated by the remarks Knox makes about himself. He speaks of feeling pride in his achievements and then undergoing a disillusioning experience. In March Knox had been invited to preach Lenten sermons at court. This honor resulted in his being indicted before the Privy Council. He may have had this recent experience in mind when he wrote the letter (that is, in April 1553).

51. Ibid., 3:337-343 (Letter 1). The letter is dated reliably in the manuscript to 23 June 1553. 
temptationis of the Devill, and youre act and work." Thoughts, he argued, were inspired by Satan and the Christian had no responsibility for them. They were not all products of one's volition, but the work of sin, an agent external to the self. And they were in any case irrelevant, for "the synner that lamentis for offence committit, and askis mercie for Chrystis sake" must be heard favorably by God. ${ }^{52}$

Once again Knox failed to speak directly to the dilemma that troubled Mrs. Bowes. He told her that she need have no concern for her spiritual weakness and inadequacy, for all that she could not do for herself Christ had already done for her. Hidden behind this promise, however, was a troublesome hurdle on the path of faith. The gift of grace assumed that the sinner first had lamented her sins, had acknowledged her unworthiness, and had surrendered unconditionally to the mercy of God. The decision to abandon all trust in works was itself the supreme work of righteousness. It was this step that Mrs. Bowes strove with all her heart to take, but she could not be confident that she succeeded. The act of surrendering all pride in one's actions in order to be saved by grace was still an act. Knox assured Mrs. Bowes that she had received grace to pass beyond this point and live by faith alone, but Mrs. Bowes was not sure that she had reasons of her own to believe him to be correct.

Under these circumstances Catholic doctrine became increasingly alluring to Mrs. Bowes. She reported that she took "pleasure and delyt" in the thought of the mass. ${ }^{53}$ She worried that Christ's blood, offered once-as opposed to its repeated application in the mass-was insufficient for the satisfaction of her sins. ${ }^{54} \mathrm{Knox}$ admonished her under no circumstances ("for feir of deth, nor for love of lyf") to give in to the impulse to commit idolatry. ${ }^{55}$ He seemed to believe that she faced a situation in which even the elect could endanger the grace the unchangeable God had given them. Knox urged her to remain true to her Protestant principles, and he iterated advice he had given often before: "Dispair not, for youre trubillis be the infallible signis of youre electioun in Chrystis bludde, being ingraftit in his bodie." ${ }^{56}$ Knox ignored the plaguing question of why the elect should have to risk their lives to avoid acts of $\sin$ when their sins were no longer imputed to them. Mrs. Bowes would have been dull-witted not to wonder how, if acts could be counted against a sinner, Knox could claim that salvation was by faith alone.

Events conspired to give Mrs. Bowes the clarity and direction that she had

52. Ibid., 3:380-381 (Letter 19). The letter was probably written just before Knox's departure from London in October 1553, for he tells Mrs. Bowes that he plans shortly to be with her.

53. Ibid., 3:369-372 (Letter 15). The letter was written in October or November 1553 when Knox had returned to the north, but was not moving about openly.

54. Ibid., 3:376-379 (Letter 18). The letter was written shortly after 6 November 1553, for it reports on an interview Knox had on that date.

55. Ibid., 3:371 (Letter 15).

56. Ibid., 3:377 (Letter 18). 
sought and failed to find in conversation with John Knox. Mary Tudor ascended the throne. Catholicism returned to England. When faced with the resurgence of Catholicism as a reality and not simply an abstract possibility, Elizabeth Bowes discovered the strength of her convictions. She made her choices. She abandoned home and family and voluntarily joined the English Protestants in exile. Despite doubts about her faith she chose to stand by it, and the few letters which Knox wrote to her later in their lives do not return to the theological questions that preoccupied their earlier correspondence. Knox had succeeded as a pastor in encouraging Mrs. Bowes to cling to her faith, but he had done less as a theologian to help her solve the problems that eluded her understanding.

Her problems were his, and in exile Knox had leisure to ponder them as never before. Knox was not a gifted systematic thinker, but in 1560 he made his "only serious attempt at an organized theological presentation": he published a book on predestination. ${ }^{57}$ Scholars have debated his motives. He may have wished to ingratiate himself with Calvin by endorsing Calvin's line of thought. ${ }^{58}$ He may have found the idea of predestination psychologically comforting as an explanation of the many failures that plagued the record of his work in the preceding years. ${ }^{59}$ Or he may simply, as he says, have been responding to a request from his colleagues to provide a defense against some English Anabaptists whose excesses discredited Protestantism.

Knox was a thinker who dealt with problems that were thrust upon him. ${ }^{60}$ He addressed particular situations and was not attracted to abstract ideas that had no immediate application in his campaign to defend the Protestant cause. His decision to wrestle in print with the meaning of election may have been sparked by a political need, but it is to be set in the context of his years of conversations with Mrs. Bowes. These discussions had brought him to confront the mystery of his own faith. To dismiss the Knox-Bowes letters as casual notes from a "spiritual counselor" to an unsophisticated or ill woman is to risk missing what they have to say about Knox's own intellectual struggles. ${ }^{61}$ Despite (or perhaps because of) her lack of formal theological training, Mrs. Bowes clearly saw the mysteries that lay at the center of Protestant preaching. Her spiritual anxiety was not mere emotional insecur-

57. Richard G. Kyle, "John Knox: The Main Themes of His Thought," Princeton Seminary Bulletin 4 (1983): 101; Kyle, "Concept of Predestination in the Thought of John Knox," p. 56. The book is entitled: An Answer to the Cavillations of an Adversary Respecting the Doctrine of Predestination, in Works, 5:21-468.

58. Richard L. Greaves, Theology and Revolution in the Scottish Reformation (Grand Rapids, Mich., 1980), pp. 28-29.

59. Pierre Janton, Concept et sentiment de l'église chez John Knox: le réformateur écossais (Paris, 1972), pp. 105-106.

60. Ian Cowan, "Review: Kyle, The Mind of John Knox," American Historical Review 90 (1985): 684-685.

61. Greaves, Theology and Revolution, p. 160. 
ity worsened by a family that opposed and misunderstood her faith. ${ }^{62}$ Profound theological problems troubled her understanding. It was not simply as a model of Christian endurance that she inspired Knox, but more as a thinker whose questions kept pace with his own. Again and again in different ways she asked Knox, "If works count for nothing, what is faith?" Although other issues occasionally surfaced in their conversations, this was the one to which she constantly brought him back.

In the end Knox could do nothing but stand by the paradox that God's power was absolute and human beings were free and responsible. He endorsed predestination, but, in the words of Richard Kyle, "one is left with the impression that the reformer never felt truly at home in the subject.",63 Knox cannot be faulted for failing to do much with a question that had challenged the intellectual resources of Paul and Augustine, thinkers far greater than he. It is to his credit that he struggled openly and long with an issue that was central to his faith. Mrs. Bowes's determination to deal with the problem of faith and works and her insistence that Knox face up to it may explain why he found her to be the mirror of his soul and an extraordinary exemplar of Christian life. There was more than a little irony in the fact that Knox, who was convinced of the inferiority of women, was forced by the company of this woman to confront difficult theological issues. Once the reformation began in Scotland, Knox turned from theology and conducted no more extensive correspondences on theological topics with women. ${ }^{64}$ In the end the male world of revolution and reformation may have offered easier challenges than the conversations of Christian women.

62. Reid, “John Knox,” p. 3.

63. Richard Kyle, The Mind of John Knox (Lawrence, Kan., 1984), p. 80, quote at p. 105.

64. His later letters to Anne Locke are primarily reports on the progress of the Reformation in Scotland. Pastoral advice is limited to warnings not to compromise with the practices of the Church of England. The Bowes letters deserve a closer look by scholars of the history of Puritan introspection. Their themes relate to those discussed in Richard Greaves, "The Puritan-Nonconformist Tradition in England, 1560-1700: Historiographical Reflections," Albion 17 (1985): 462; and Dewey Wallace, Puritans and Predestination: Grace in English Protestant Theology, 1525-1695 (Chapel Hill, 1982). 